\title{
Predicting suitable areas for Baccaurea angulata in Kalimantan, Indonesia using Maxent modelling
}

\author{
GUNAWAN $^{1, \boldsymbol{\varphi}}$, SULISTIJORINI ${ }^{2}$, TATIK CHIKMAWATI ${ }^{2}$, SOBIR $^{3}$ \\ ${ }^{1}$ Department of Biology, Faculty of Mathematics and Natural Sciences, Universitas Lambung Mangkurat. J1. A. Yani Km 36.4, Banjarbaru 70714, South \\ Kalimantan, Indonesia. Tel./fax.: +62-511-4773112, `email: gunawan@ulm.ac.id. \\ ${ }^{2}$ Department of Biology, Faculty of Mathematics and Natural Sciences, Institut Pertanian Bogor. Jl. Meranti, Dramaga, Bogor 16680, West Java, \\ Indonesia \\ ${ }^{3}$ Department of Agronomy and Horticulture, Faculty of Agriculture, Institut Pertanian Bogor. Jl. Kamfer, Dramaga, Bogor 16680, West Java, Indonesia
}

Manuscript received: 1 March 2021. Revision accepted: 18 April 2021.

\begin{abstract}
Gunawan, Sulistijorini, Chikmawati T, Sobir. 2021. Predicting suitable areas for Baccaurea angulata in Kalimantan, Indonesia Using MaxEnt Modelling. Biodiversitas 22: 2646-2653. Baccaurea angulata Merr. or 'Belimbing Dayak' is an underutilized fruit indigenous in Kalimantan. This species potentially used as edible fruit and medicinal plant. Unfortunately, the forest conversion to oil palm and rubber plantations causes decreasing the habitat of $B$. angulata. However, little is known about the occurrences and suitable habitat of $B$. angulata in Kalimantan. This investigation is might be the first study report on predicting the distribution of $B$. angulata in Kalimantan using MaxEnt (Maximum Entropy). The results show that four variables namely solar radiation in October, altitude, precipitation of warmest quarter, and gloslope are significant factors determining B.angulata's suitable habitat. The location of suitable habitat for $B$. angulata is accordant with the real present distribution. The extent of potentially suitable area was significantly larger than the present occurrence of $B$. angulata in Kalimantan. The highest suitable areas identified in this study covered West Kalimantan and South Kalimantan. They included parts of SB (Sambas), LD (Landak), SG (Sanggau), SK (Sekadau) and BK (Bengkayang) of West Kalimantan Provinces, and TL (Tanah Laut), BN (Banjar) of South Kalimantan Provinces. The MaxEnt model performed better than random method with an Area Under Curve (AUC) value of 0.937 and it was statistically significant. It indicated that MaxEnt model was highly accurate and informative for habitat suitability of $B$. angulata. The predicted model of suitable areas can be used for management, monitoring, cultivation and future conservation of $B$. angulata.
\end{abstract}

Keywords: Phyllanthaceae, Kalimantan, habitat suitability, conservation, modeling

\section{INTRODUCTION}

Baccaurea angulata, known as 'belimbing merah' or 'belimbing dayak', is a member of the Phyllanthaceae family. Biogeographically, it is known to be distributed in Borneo (Haegens 2000) and Natuna (Gunawan et al. 2018). it is a small tree about 5-15 m tall, with cauliflorous flower and fruit, and produces red fruits with a star-like shape. The pericarp and aryl of the fruit are edible with a sweet to acidic flavor. The wood is used for light construction, including tables and chairs (Lim 2012). In addition, several local people in West Kalimantan, Central Kalimantan, East Kalimantan use this fruit as cooking spice, fresh fruit, and sweets.

Nonetheless, B. angulata has not been cultivated with most of them are found naturally growing in wild habitat of the forest, therefore the plant is not popularly known by the public. The plant is considered to have less economic value, compared to Rambai (B. motleyana), and other relatives. The fruit of $B$. angulata has the potential to be developed as a food source and for medicinal purposes. Phytochemical analyses of the fruit peel of $B$. angulata show the presence of protein, carbohydrates, fiber, minerals, vitamin C (Voon and Kueh 1999), vitamins A, E, and anthocyanin compounds (Norazlanshah et al. 2015; Ahmed et al. 2014). A report by Mikail et al. (2014; 2015) stated $B$. angulata juice is able to prevent atherosclerosis, inhibit lipid peroxidase activity, and induce antioxidant enzyme activity. This also has the potential to be a source of natural ingredients for cancer treatment (Adam and Rasad 2015), antioxidant source (Ibrahim et al. 2013), as well as antimicrobial activity (Momand et al. 2014). Viewed from ecological perspective, $B$. angulata plant has important values as food for some species of birds, gnats, monkeys, and orangutans (Haegens 2000).

While $B$. angulata has great potential uses, its population in Kalimantan is declining due to habitat loss caused by increased conversion of forests into oil palm and rubber plantations, as well as community settlement, and road construction. According to Yang et al. (2013) habitat degradation, fragmentation, over-exploitation, as well as an increasing human population, are some important factors responsible for species loss around the world. In the Indonesian context, species extinction is mostly caused by excessive exploration, intrinsic biological factors (such as restricted ranges and small population sizes), and logging activities (Budiharta et al. 2011)

Despite the threats to its population continues, information regarding its distribution and location suitable as the habitat of $B$. angulata has never been available, making it difficult for sustainable utilization and conservation of this species. This information is useful as the baseline information to record the populations, habitat 
diversity and further purposes. $\mathrm{Xu}$ et al. (2018) stated that habitat suitability modeling can help to determine the potential location for conservation and cultivation of a species with particular interest. The modeling is also useful in understanding the environmental factors affecting $B$. angulata species distribution, thus, helping to improve conservation and cultivation efforts.

Nowadays, there are increasing number of tools in habitat suitability modeling, including MaxEnt (Maximum Entropy)(Phillips 2004), BIOCLIM (Busby 1991), DOMAIN (Carpenter et al. 1993), generalized additive model (GAM) (Yee and Mitchell 2002), GLM (Lehman et al. 2002), and BIOMAPPER (Hirzel et al. 2002). Each tool is unique with particular advantages and disadvantages. Marcer et al. (2013) stated that MaxEnt can be considered one of the best and extensively used habitat suitability modeling tools among others. Several advantages of MaxEnt include the requirement of only presence data of species, the ability to run with a small amount of data, the high accuracy of prediction results, the high reproducibility, as well as the ability to predict the most discriminant environmental factors (Fois et al. 2018).

This study aims to predict suitable habitats of $B$. angulata in Kalimantan using MaxEnt. We expect the results of this study to provide information regarding the potential distribution of $B$. angulata in Kalimantan, identify the currently suitable areas for conservation and cultivation, and identify environmental factors with a high correlation to this distribution. To our knowledge, our study is the first to investigate the habitat suitability areas of $B$. angulata using a modeling tool to support its conservation and cultivation.

\section{MATERIALS AND METHODS}

\section{Species occurrences data}

In this study, explorations or field surveys were carried out in 3 provinces of Kalimantan, Indonesia, namely West Kalimantan (Sanggau, Entikong, Ngabang, Nangapinoh, Sompak, Sarumbi, Kembayan, Sambas, and Sintang), East Kalimantan (Botanical Garden of Unmul Samarinda), and Central Kalimantan (Pangkalan Bun and Muara Teweh). The location selection in the field was based on information from Herbarium Bogoriense (BO), Herbarium Wanariset (WAN), and local people knowledgeable on the existence of $B$. angulata plant. The appearance of the plant to identify the species is presented in Figure 1.

Geographical coordinates of the occurrence of the plants in the field were recorded using the Garmin Etrex 30 type Global Position System (GPS). The data were transferred into Microsoft Excel and saved in CSV format to be used for habitat suitability modeling with MaxEnt. In total, 114 coordinate points were obtained from the exploration/ survey and a distribution map was made (Figure 2).

\section{Environmental variables}

This research used 23 environmental variables consisting of 19 bioclimatic variables, soil type, slope, altitude, and solar radiation (12 months) (Tabel 1). Bioclimatic variable and solar radiation were downloaded from the global climate database WordClim (www.worldclim.org, the new version 2.0), for the recent period. In addition, the altitude data was also downloaded from the WordClim website, based on the digital elevation model. This database has been used extensively in habitat suitability modeling (Khanum et al. 2013) and is widely used in the Asian region (Rana et al. 2017). Slope was downloaded from www.fao.org. Soil types of Kalimantan were collected freely from indonesiageospasial.com. Those data were not ready for use, then the data were processed and combined using ArcGis version 10.3. All downloaded data in this study has a resolution of 30 acr second grid (1 km) (Ficks and Hijmans 2017).

Worthington et al. (2016) suggested selecting and using environmental factors with a major influence, in order to obtain an accurate and informative habitat suitability model. Based on the Jackknife analysis evaluating the contribution of each environmental variable to the resulting model, 16 environmental variables were not used due to the lack of contribution to the model making (percent contribution = $0)$. Wei et al. 2018 also suggested not to use environmental variables with a small average contribution $(<6 \%)$ or permutation importance $(<6 \%)$. The contribution percentage and permutation are two important factors for understanding and measuring the environmental variable's contribution as well as importance to the model. Therefore, the environmental variables used in B. angulata habitat suitability map model for the current period were srad_10 (solar radiation in October), altitude, gloslope, bio_15 (precipitation seasonality), and bio_18 (precipitation of warmest quarter).

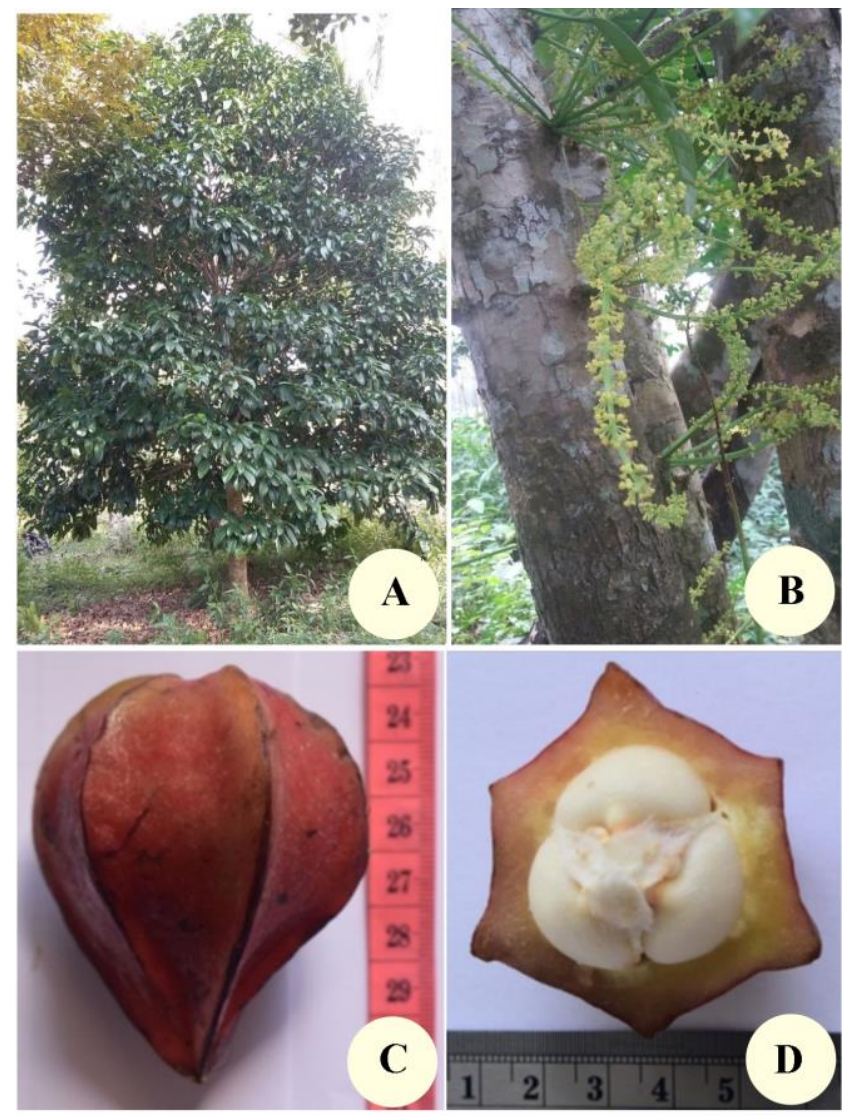

Figure 1. The appearance of Baccaurea angulata: A. Habitus; B. Flower; C. Fruit; D. Transversal section of fruit. 


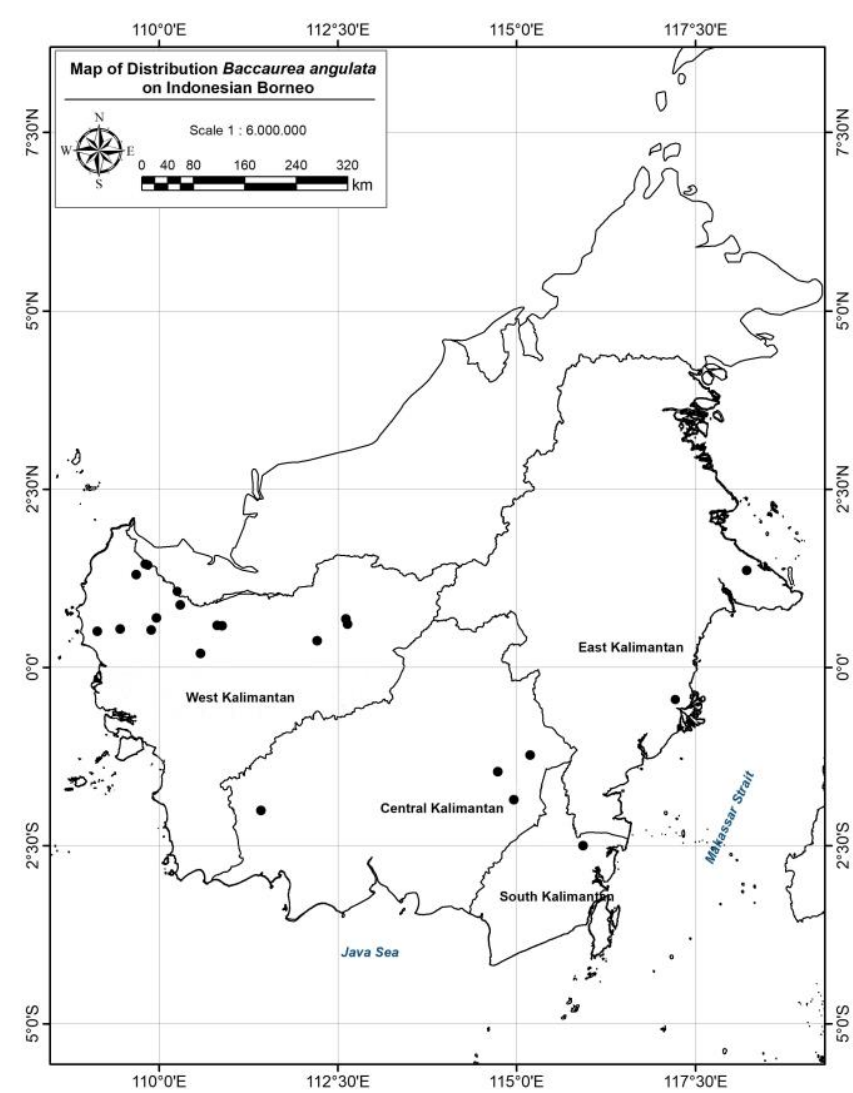

Figure 2. Current distibutions of $B$. angulata in Kalimantan, including West Kalimantan, Central Kalimantan, South Kalimantan, and East Kalimantan, obtained from field survey.

Tabel 1. Twenty-three candidate environmental variables for use in MaxEnt models.

\begin{tabular}{ll}
\hline Code & Parameter \\
\hline Altitude* & Altitude above sea level \\
GloSlope* & - \\
Soil type & - \\
Srad* & Solar radiation (12 month) \\
Bio 1 & Mean annual temperature \\
Bio 2 & Mean diurnal range \\
Bio3 & Isothermality \\
Bio 4 & Temperatur seasonality \\
Bio 5 & Maximum temperature of warmest month \\
Bio 6 & Minimum temperature of coldest month \\
Bio 7 & Temperature annual range \\
Bio 8 & Mean temperature of wettest quarter \\
Bio 9 & Mean temperature of driest quarter \\
Bio 10 & Mean temperature of warmest quarter \\
Bio 11 & Mean temperature of coldest quarter \\
Bio 12 & Annual precipitation \\
Bio 13 & Precipitation of wettest month \\
Bio 14 & Precipitation of driest month \\
Bio $15^{*}$ & Precipitation seasonality \\
Bio 16 & Precipitation of wettest quarter \\
Bio 17 & Precipitation of driest quarter \\
Bio $18^{*}$ & Precipitation of warmest quarter \\
Bio 19 & Precipitation of coldest quarter \\
Not & $*$ Astein
\end{tabular}

Note: *) Asterisks indicated variables selected for use in MaxEnt models

\section{Modeling species distribution}

This study used MaxEnt version 3.4.1 (Phillips et al. 2017) to create predicted suitability maps of $B$. angulata on the default setting. The software was freely obtained from https://biodiversityinformatics.amnh.org/ open_source/ maxent/. Meanwhile, the contribution and importance of each environmental variable on the habitat suitability model of $B$. angulata were performed with a jackknife test (Promnikorn et al. 2019), and the receiving operating curve (AUC) area was applied to evaluate the performance model. According to Zhu et al. (2017), AUC values range from 0 (lowest suitability) to 1 (maximum suitability), and a value below 0.5 indicates the resulting model is not better, compared to random and uninformative data, while a value of 1.0 shows the resulting model is very good and informative (Swets, 1988). Subsequently, the analysis results from MaxEnt models predicting $B$. angulata suitability (0-1 range) were imported into Diva Gis software version 7.5 for display and further analysis (Hijmans et al. 2012). Based on IPCC (2007) and Wei et al. (2020) habitat suitability levels on the model map generated from MaxEnt can be grouped into 4 classes, namely least suitable $(0.0-0.2)$, low suitability $(0.2-0.4)$, medium suitability (0.4-0.6), and high suitability (0.6-1).

\section{RESULTS AND DISCUSSION}

\section{Model performances}

In this study, the habitat suitability model map produced by MaxEnt was analyzed using thresholdindependent ROC analysis. Philips et al. (2006) stated the value of the Area Under Curve (AUC) represents the model's performance, based on the response curve to each predictor variable contributing to the habitat. The model habitat suitability with highest AUC value indicated that the model has the best performer. An AUC value below 0.50 indicates the resulting prediction model is not good (Swets 1988), while a value of 1 shows the model has high accuracy. The resulting AUC value for the prediction model B. angulata is 0.937 (Figure 3), and based on Swets (1988) this value can be categorized as excellent and accurate, suggesting that the selected environmental variable for the current distribution of $B$. angulata very well. The result prediction model for $B$. angulata has a very high correlation with the actual occurrence location in its natural habitat.

The environmental variable with the highest mean contributions were srad_10 (solar radiation in October, $48.9 \%$ ), altitude (17.5\%), bio_18 (precipitation of warmest quarter, 13.6\%), gloslope (10\%), bio_15 (precipitation seasonality, $9.9 \%$ ) which accounted for $99.9 \%$ to the model prediction. Among them, srad_10 (solar radiation in October) was the topmost important predictor which contributed $48.9 \%$. Considering the importance of permutation, bio_18 (precipitation of warmest quarter, $30 \%$ ), srad_10 (solar radiation in October, 27.8\%), altitude (22.9\%), bio_15 (precipitation seasonality, 14.7\%). According to the Jackknife test, srad_10 (solar radiation in October), altitude, gloslope, and bio_18 (precipitation of 
warmest quarter) are the main environmental variables (Figure 4). However, the environmental variable with the highest gain value is srad_10 (solar radiation in October). This implies srad_10 (solar radiation in October) plays an important role in the formation of predictive models for $B$. angulata habitat suitability, and consequently, has a major influence on the plant's distribution.

In addition, environmental variables are very important factors in plant cultivation and conservation management with a role in plant growth and development. Sun et al. (2013) showed biophysical factors such as topography (slope, aspect, altitude, and soil), climate, and soil (soil physical, chemical, and biological properties) are important factors influencing the plant's growth. Meanwhile, Zhang et al. (2018) stated climatic factors are very important in affecting plant regeneration, growth, and spread. A study by Asanok et al. (2020) reported habitat suitability modeling indeed helps to improve understanding of the relationship between plants and respective habitats through incorporating the current location, microclimate, topographical, and edaphic factor data.

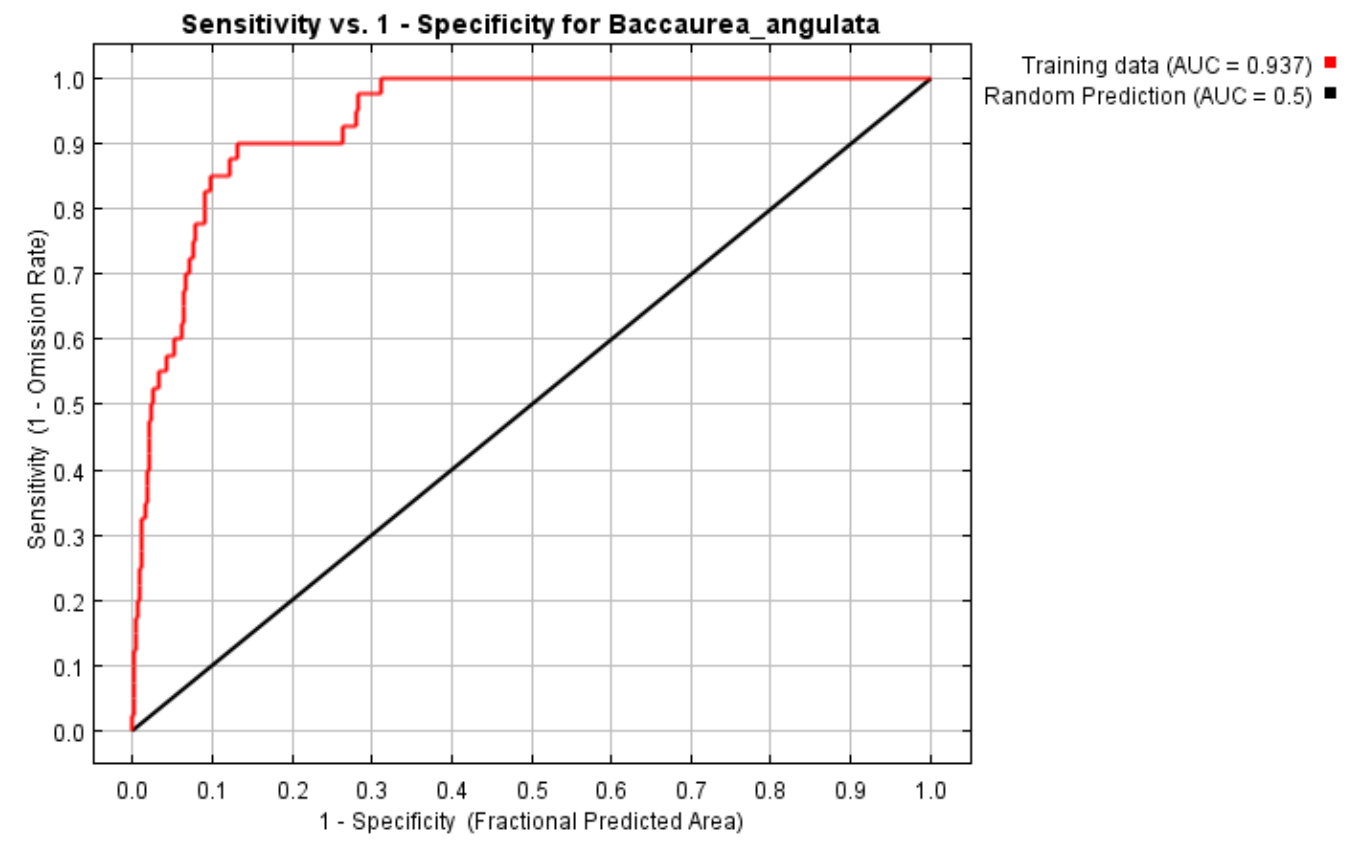

Figure 3. The results of the AUC curves in developing B. angulata habitat suitability model.

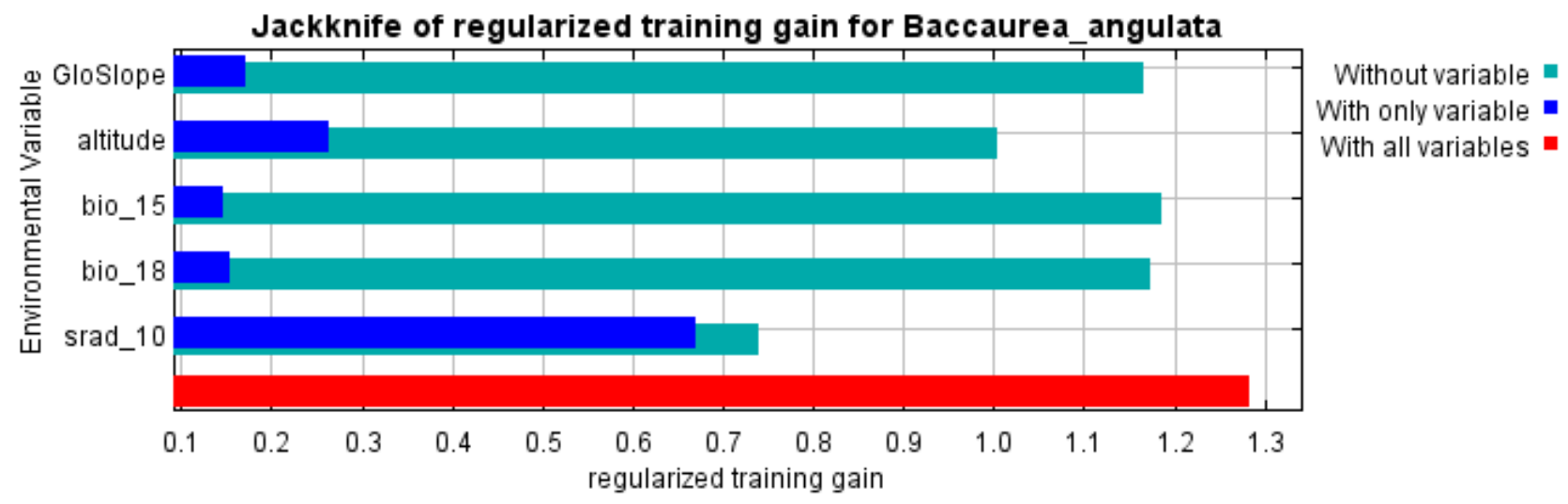

Figure 4. The results of the jackknife test of variable's contributions. 


\section{Variable's response to suitability}

Environmental variables are closely related to the possible plant distribution in a location. Figure 5 shows the relationship between environmental variables and the possible distribution of $B$. angulata in the response curve generated by MaxEnt. This curve illustrates the quantitative relationship between environmental variables and the logistic probability of presence (also known as habitat suitability), and these depend on the understanding of the species' ecological niche (Yi et al. 2016). Furthermore, this provides highly significant information required to determine the environmental variables plants need to grow optimally (Esfanjani et al. 2018). Therefore, environmental factors affecting plants must be considered in conservation development plans and management.

According to Thery (2001), solar radiation is a very significant environmental variable influencing species regeneration. The optimal solar radiation required by $B$. angulata is $15.000-16.000$, as indicated by the response curves srad_10. The observations at the research location indicated B. angulata grew a lot in open locations. Based on the survey, $B$. angulata plants began to flower in August-October, and this is in line with the previous research by Haegens (2000), stating the plant begins to flower in August-September. Thus, solar radiation has an important role in the distribution of locations with suitable habitats for B. angulata. Rezazadeh et al. (2018) reported short length of radiation is a factor controlling the induction and initiation of flowering in several plant species, while Nurtjahjaningsih et al. (2012) explained flowering is affected by external factors in the form of sufficient sunlight and nutrients. Another environmental variable influencing the habitat suitability model of $B$. angulata, is altitude. According to the response curve, the suitable altitude range is $50-500 \mathrm{~m}$ a.s.1, and observations during the survey also show these plants are found at locations with an altitude of $50-500 \mathrm{~m}$ a.s.l. This statement is in line with Haegens (2000) report, stating B. angulata grows at an altitude of $0-800 \mathrm{~m}$ a.s.l in a natural habitat and is found in primary and secondary forests. Based on the response curve, the higher the altitude of a place, the lower the suitability of its habitat. Previous studies by Berli et al. (2013) and Dogra et al. (2013) showed altitude greatly affects plant growth, structure, function, and metabolism.

Furthermore, Grytnes et al. (2002) and Cai et al. (2012) reported optimum altitude range affects biomass production, enzymatic activity, as well as photosynthesis, while Adhikari et al. (2018) explained this causes altitude to affect the plant distribution. The response curve for gloslope showed the highest probability of $B$. angulata presence at the slope greater than $10^{\circ}$. Moreover, bio_18 (precipitation of warmest quarter) was variable related to rainfall, and the optimum range was $300-700 \mathrm{~mm}$.

\section{Predicted current potential distribution}

The prediction model map for $B$. angulata habitat suitability was created using the MaxEnt program, based on the data present. Figure 6 shows the result of field surveys and current environmental factors. Meanwhile, the map of the habitat suitability prediction model produced by MaxEnt has a suitability value of 0 to 1 .

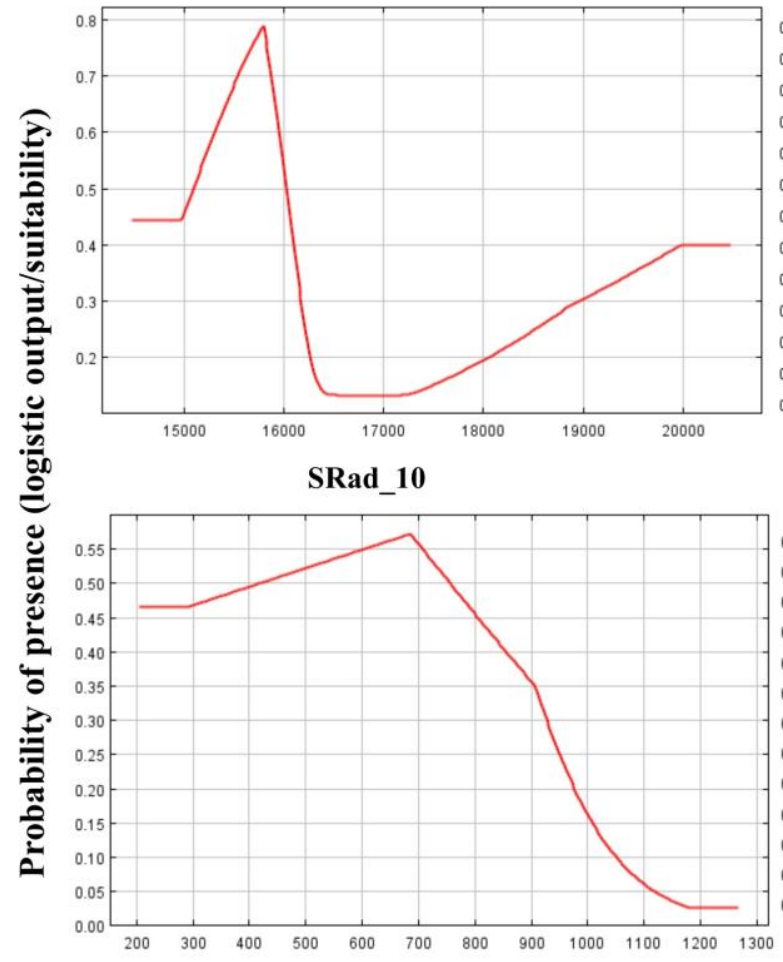

Bio_18

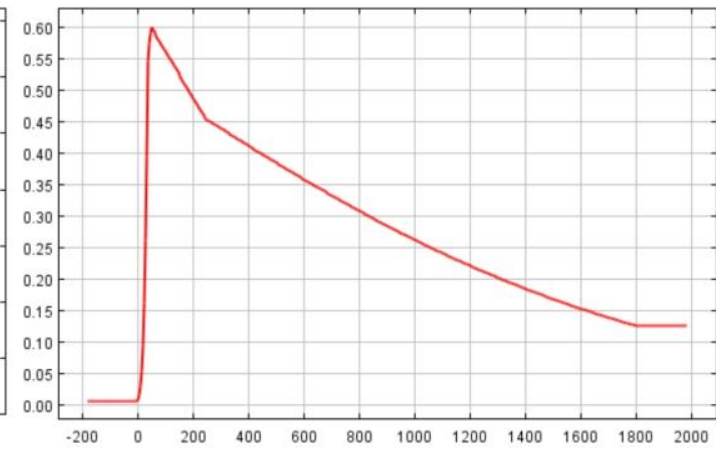

Altitude

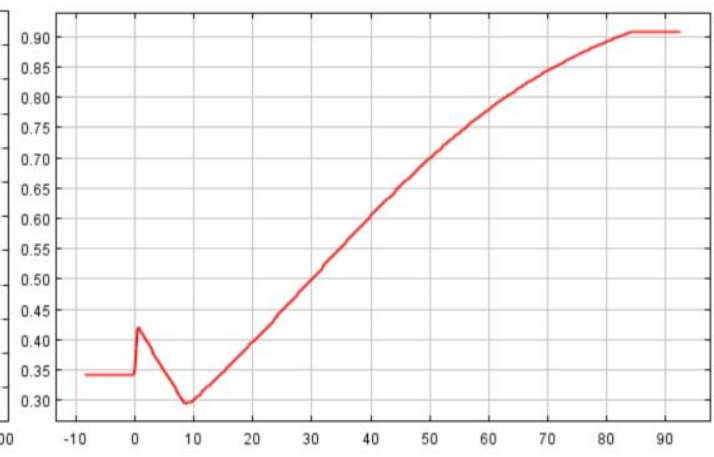

GloSlope

Figure 5. Response curves of four key climatic variables used in the ecological niche model B. angulata. Srad_10 (solar radiation in October); altitude; bio_18 (precipitation of warmest quarter); gloslope 


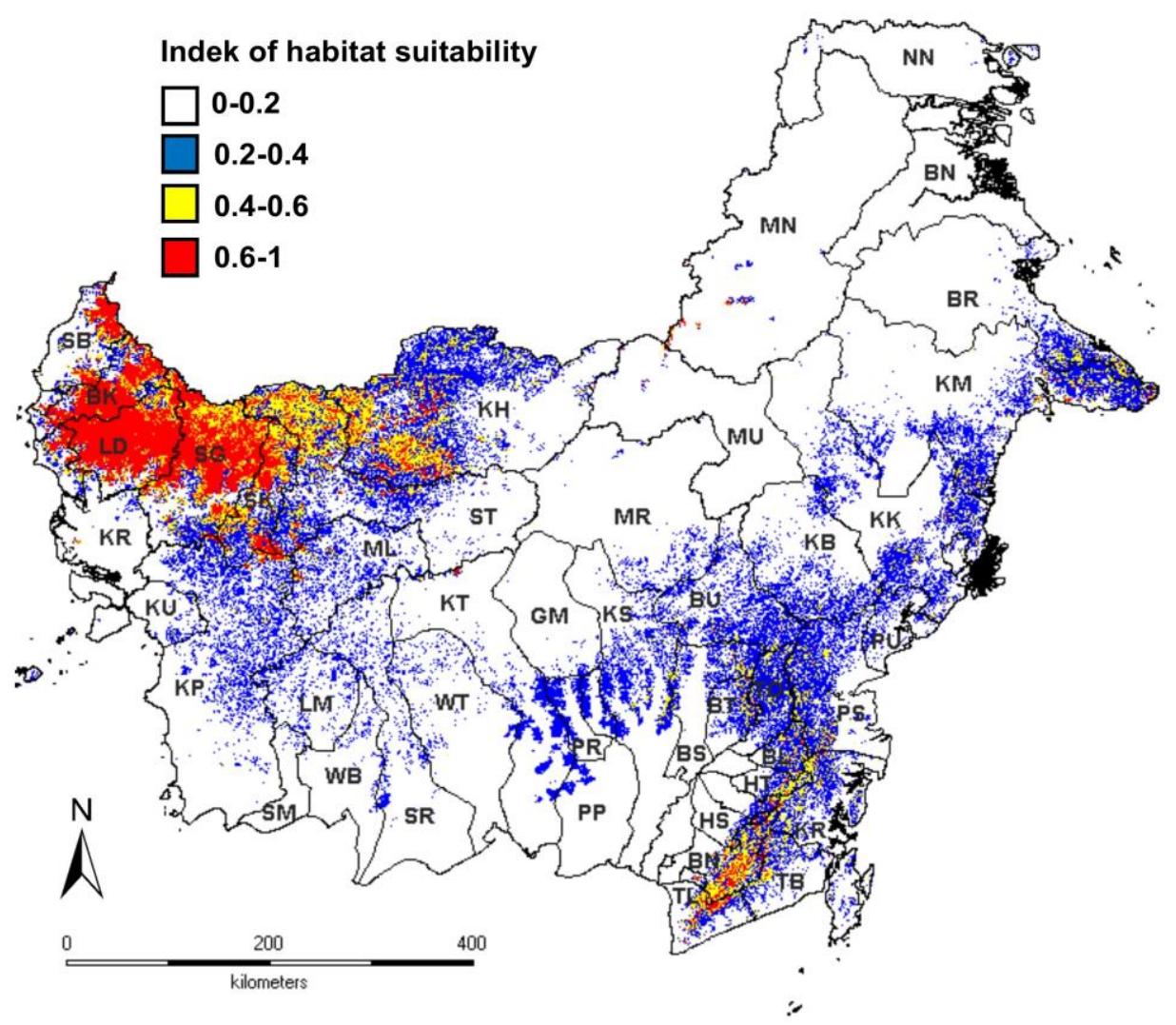

Figure 6. Map for potential current distribution suitability of B. angulata in Kalimantan according to occurence records. West Kalimantan: SB (Sambas), BK (Bengkayang), LD (Landak), SG (Sanggau), SK (Sekadau), ST (Sintang), KH (Kapuas Hulu), ML (Melawi), KR (Kubu Raya), KU (Kayong Utara), KP (Ketapang). Central Kalimantan: SM (Sukamara), LM (Lamandau), WB (Kotawaringin Barat), SR (Seruyan), WT (Kotawaringin Timur), KT (Katingan), PP (Pulang Pisau), PR (Palangka Raya), GM (Gunung Mas), KS (Kapuas), MR (Murung Raya), BU (Barito Utara), BT (Barito Timur), BS (Barito Selatan). South Kalimantan: TL (Tanah Laut), TB (Tanah Bumbu), BN (Banjar), HS (Hulu Sungai Selatan), KR (Kota Baru), HT (Hulu Sungai Tengah), BL (Balangan), TO (Tabalong). East Kalimantan: PS (Paser), PU (Paser Utara), KB (Kutai Barat), KK (Kutai Kartanegara), MU (Mahakam Ulu), KM (Kutai Timur), BR (Berau). North Kalimantan: MN (Malinau), NN (Nunukan), BN (Bulungan)

The locations with high habitat suitability in West Kalimantan were discovered to be SB (Sambas), LD (Landak), SG (Sanggau), BK (Bengkayang), and SK (Sekadau) regencies, while the locations with medium habitat suitability in West Kalimantan were KH (Kapuas Hulu) and ST (Sintang). The lowly suitable habitat were found a part of KH (Kapuas Hulu), ML (Melawai), and KP (Ketapang). Meanwhile, the locations with high habitat suitability in South Kalimantan were found to be TL (Tanah Laut), and BN (Banjar), medium habitat suitability found in TB (Tanah Bumbu), KR (Kota Baru), HS (Hulu Sungai Selatan), HT (Hulu Sungai Tengah), BL (Balangan) and TO (Tabalong). In addition to having high suitability, some areas in West Kalimantan also have low suitability locations, which also occurs in South Kalimantan. However, other Kalimantan regions (East Kalimantan, Central Kalimantan, and North Kalimantan) have low and least levels of habitat suitability. Based on map potential suitability habitat for cultivation was significantly larger than occurence of $B$. angulata in Kalimantan. Previous studies on the distribution of $B$. angulata have shown the distribution is most prominent in West Kalimantan. This is consistent with the habitat suitability model map created using MaxEnt. The environmental factors with a major contribution to $B$. angulata's habitat suitability model map is solar radiation in October, followed by altitude. Based on field observations, West Kalimantan has higher solar radiation, compared to the other locations, and this is related to the region's position on the equator.

The MaxEnt analysis shows locations with high habitat suitability are dominant in West Kalimantan. This is consistent with the conditions at the time of field survey, recording the presence of numerous $B$. angulata plants in West Kalimantan. However, the plant was also found in areas with low habitat suitability, but in small numbers. The presence of this plant in low suitability locations indicates possible high adaptability to changing environmental factors or a wide ecological range. This is probably developed at the location and is believed to imply a high level of genetic diversity in the plant.

This study is the first to create a map of the habitat suitability model for $B$. angulata in Kalimantan using MaxEnt. Species distribution modeling (SDM) provides highly significant information for cultivation as well as 
conservation management, and shows the relationship between species as well as habitat by combining data on presence, microclimate, topography, and edaphic factors (Asanok et al. 2020). Furthermore, SDM also provides information on environmental factors with the most influence on species distribution. Therefore, the $B$. angulata habitat suitability distribution map is able to help researchers and conservators determine the plant's conservation or cultivation location. Thus, locations with a high level of suitability are maintained or prioritized, rather than converted into plantations or housing, making conservation and cultivation possible.

\section{ACKNOWLEDGEMENTS}

The authors would like to thank head and staff of Herbarium Bogoriense (BO) and Wanariset Herbarium (WAN) for all the facilities provided. We also pay thanks to all parties involved with me in present study.

\section{REFERENCES}

Adam M, Rasad MSBBA. 2015. Expression of matrix metalloproteinase13 in human skin melanoma cancer treated by Baccaurea angulata in vitro. J Basic Appl Res 1 (1): 21-28. DOI: 10.51152.

Adhikari P, Shin MS, Jeon JY, Kim HW, Hong S, Seo C. 2018. Potential impact of climate change on the species richness of subalpine plant species in the mountain national parks of South Korea. J Ecol Environ 42 (36). DOI: 10.1186/s41610-018-0095-y.

Ahmed IA, Mikail MA, Ibrahim M, Hazali N, Rasad MSBA, Gani RA, Wahab RA, Arief SJ, Yahya MNA. 2014. Antioxidant activity and phenolic profile of various morphological parts of underutilized Baccaurea angulata fruit. Food Chem 172:778-787.

Asanok L, Kamyo T, Marod D. 2020. Maximum entropy modeling for the conservation of Hopea odorata in riparian forest, central Thailand. Biodiversitas 12 (10): 4663-4670. DOI: 10.13057/biodiv/d211027.

Berli FJ. Alonso R. Bressan-Smith R. Bottini R. 2013. UV-B impairs growth and gas exchange in grapevines grown in high altitudes. Physiologia Plantarum 149 (1): 127-140. DOI: 10.1111/ppl.12012.

Budiharta S, Widyatmoko D, Irawati, Wiriadinata H, Rugayah, Partomihardjo T, Ismail, Uji T, Keim AP, Wilson, K. 2011. The processes that threaten Indonesian plants. Oryx 45: 172-179. DOI: 10.1017/S0030605310001092.

Busby JR. 1991. BIOCLIM: a bioclimate analysis and prediction system. Plant Prot Q 6: 8-9.

Cai ZQ, Jiao DY, Tang SX, Dao XS, Lei YB, Cai CT. 2012. Leaf photosynthesis, growth, and seed chemicals of Sacha Inchi plants cultivated along an altitude gradient. Crop Sci 52 (4): 1859-1867. DOI: $10.2135 /$ cropsci2011.10.0571.

Carpenter G, Gillison AN, Winter J. 1993. DOMAIN: a flexible modelling procedure for mapping potential distributions of plants and animals. Biodivers Conserv 2: 667-80. DOI: 10.1007/BF00051966.

Dogra V, Ahuja PS, Sreenivasulu Y. 2013. Change in protein content during seed germination of a high altitude plant Podophyllum hexandrum Royle. J Proteomics 78 (78): 26-38. DOI: 10.1016/j.jprot.2012.10.025.

Esfanjani J, Ghorbani A, Chahouki MAZ. 2018. Maxent modeling for predicting impacts of environmental factors on the potential distribution of Artemisia aucheri, Bromus tomentellus, and Festuca ovina in Iran. Pol J Environ Stud 27 (3): 1041-1047. DOI: $10.15244 /$ pjoes/76496

Fick SE, Hijmans RJ. 2017. WorldClim 2: New 1-km spatial resolution climate surfaces for global land areas. Intl J Climatol 37 (12): $4302-$ 4315. DOI: $10.1002 /$ joc. 5086.

Fois M, Cuena-Lombraña A, Fenu G, Bacchetta G. 2018. Using species distribution models at a local scale to guide poorly known species, review: methodological issues and future directions. Ecol Model 385: 124-132. DOI: 10.1016/j.ecolmodel.2018.07.018.

Gunawan, Chikmawati T, Sobir, Sulistijorini. 2018. Distribution, morphological variation and new variety of Baccaurea angulata (Phyllantaceae). Floribunda 6 (1): 1-11. DOI: 10.32556/floribunda.v6i1.2018.226.

Grytnes JA, Vetaas OR. 2002. Species richness and altitude: a comparison between null models and interpolated plant species richness along the Himalayan altitudinal gradient, Nepal. Am Nat 159 (3): 294-304. DOI: $10.1086 / 338542$.

Haegens R. 2000. Taxonomy, phylogeny, and biogeography of Baccaurea, Distichirhops, and Nothobaccaurea (Euphorbiaceae). Blumea Suppl. 12 (1): 1-218.

Hijmans RJ, Guarino L, Mathur P. 2012. DIVA-GIS version 7.5 Manual. https://www.diva-gis.org/

Hirzel A, Guisan A. 2002. Which is the optimal sampling strategy for habitat suitability modelling. Ecol Model 157: 331-41. DOI: 10.1016/S0304-3800(02)00203-X.

Ibrahim D, Hazali N, Jauhari N, Omar MN, Yahya MNA, Ahmed IA, Mikail M A, Ibrahim M. 2013. Physicochemical and antioxidant characteristics of Baccaurea angulata fruit juice extract. Afr J Biotech 12 (34): 5333-5338. DOI:10.5897/AJB2013.12989.

IPCC. 2007. Contribution of Working Groups I, II, III to the Fourth Assessment Report of the Intergovernmental Panel on Climate Change. Climate Change 2007, Synthesis Report, Geneva.

Khanum R, Mumtaz AS, Kumar S. 2013. Predicting impacts of climate change on medicinal Asclepiads of Pakistan using Maxent modeling. Acta Oecol 49: 23-31. DOI: 10.1016/j.actao.2013.02.007.

Lehmann A, Overton JM, Leathwick JR. 2002. Erratum to GRASP: generalized regression analysis and spatial prediction. Ecol Model 157: $189-207$.

Lim TK. 2012. Edible Medicine and Non-Medicine Plants. Volume 4. Springer, London.

Marcer A, Sáe L, Molowny-Horas R, Pons X, Pino J. 2013. Using species distribution modelling to disentangle realised versus potential distributions for rare species conservation. Biol Cons 166: 221-230. DOI: 10.1016/j.biocon.2013.07.001.

Mikail MA, Ahmed IA, Ibrahim M, Hazali N, Rasad MSBA, Ghani RA, Wahab RA, Arief SJ, Isa MLM, Draman S, Ishola AA, Yahya MNA. 2014. Changes in the markers of atherosclerosis following administration of belimbing dayak (Baccaurea angulata) fruit juice in experimental rabbits fed with cholesterol diet. Intl J Adv Agric Environ Eng 1(1): 151-154. DOI:10.15242/IJAAEE.C614516.

Mikail MA, Ahmed IA, Ibrahim M, Hazali N, Rasad MSBA, Ghani RA, Hashim R, Wahab RA, Arief SJ, Isa MLM, Draman S, Yahya MNA. 2015. Baccaurea angulata fruit inhibits lipid peroxidation and induces the increase in antioxidant enzyme activities. Eur J Nutr 55 (4): 1435-1444. DOI: 10.1007/s00394-015-0961-7.

Momand L, Zakaria R, Mikail M, Jalal T, Ibrahim M, Wahab RA. 2014. Antimicrobial effect of Baccaurea angulata fruit extracts against human pathogenic microorganisms. Merit Res J Med Med Sci 2(10): 229-237. DOI:10.4172/2167-0412.1000172.

Norazlanshah, Afiq M, Muhammad, Masri M. 2015. Determination of phytochemicals and vitamin content of underutilized Baccaurea angulata fruit. J Pharm Phytochem 4 (4): 192-196.

Nurtjahjaningsih, Sulistyawati ILG, Rimbawanto WA. 2012. Karakteristik pembungaan dan sistem perkawinan Nyamplung (Calophyllum inophyllum) pada hutan tanaman di Watusipat, Gunung Kidul. Jurnal Pemuliaan Tanaman Hutan 6 (2): 65-80. [Indonesian]

Phillips SJ, Dud'k M, Schapire RE. 2004. A maximum entropy approach to species distribution modeling. Proceedings of the Twenty-First International Conference on Machine Learning 83: 655-662.

Philips SJ, Anderson RP, Schapire RE. 2006. Maximum entropy modeling of species geographic distributions. Ecol Model 190: 231-259. DOI: 10.1016/j.ecolmodel.2005.03.026.

Phillips SJ, Robert PA, Dudik M, Schapire RE, Blair M. 2017. Opening the black box: an open-source release of Maxent. Ecography 887-893. DOI: $10.1111 /$ ecog.03049.

Promnikorn K, Jutamanee K, Kraichak E. 2019. MaxEnt model for predicting potential distribution of Vitex glabrata R.Br. in Thailand. Agr Nat Resour 53: 44-48.

Rana SK, Rana HK, Ghimire SK, Shrestha KK, Ranjitkar S. 2017. Predicting the impact of climate change on the distribution of two threatened Himalayan medicinal plants of Liliaceae in Nepal. J Mt Sci 14 (3): 558-570. DOI: 10.1007/s11629-015-3822-1. 
Rezazadeh A, Harkess RL, Telmadarrehei T. 2018. The effect of light intensity and temperature on flowering and morphology of potted red firespike. Horticulture 4 (36): 1-7. DOI:10.3390/horticulturae4040036.

Sun J, Cheng GW, Li WP, Sha YK, Yang YC. 2013. On the variation of NDVI with the principal climatic elements in the Tibetan Plateau. Remote Sens 5 (4): 1894-911. DOI: 10.3390/rs5041894.

Sweats JA. 1988. Measuring the Accuracy of diagnostic systems. Science 240: 1285-1293. DOI: $10.1126 /$ science. 3287615 .

Thery M. 2001. Forest light and its influence on habitat selection. Plan Ecol 153(1-2): 251-261. DOI: 10.1023/A:1017592631542.

Voon BH, Kueh HS. 1999. The nutritional value of indigenous fruits and vegetables in Sarawak. Asia Pac J Clin. Nutr 8: 24-31. DOI: 10.1046/j.1440-6047.1999.00046.x.

Wei B, Wang R, Hou K, Wang X, Wu W. 2018. Predicting the current and future cultivation regions of Carthamus tinctorius L. using Maxen model under climate change in China. Global Ecology and Conservation 16: e00477. DOI: 10.1016/j.gecco.2018.e00477.

Wei J, Kai H, Yunyun L, Jiufeng W. 2020. Predicting the potential distribution of the vine mealybug, Planococcus ficus under climate change by MaxEnt. Crop Prot 137: 105268. DOI: 10.1016/j.cropro.2020.105268.

Worthington TA, Zhang T, Logue DR, Mittelstet AR, Brewer SK. 2016. Landscape and flow metrics affecting the distribution of a federallythreatened fish: improving management, model fit, and model transferability, Ecol Model 342: 1-18. DOI: 10.1016/j.ecolmodel.2016.09.016

Xu X, Zhang H, Yue J, Xie T, Xu Y, Tian Y. 2018. Predicting shifts in the suitable climatic distribution of walnut (Juglans regia L.) in China: maximum entropy model paves the way to forest management. Forest 9 (103): 1-15. DOI: 10.3390/f9030103.

Yang XQ, Kushwaha SPS, Saran S, Xu J, Roy PS. 2013. Maxent modeling for predicting the potential distribution of medicinal plant Justicia adhatoda L: in Lesser Himalayan foothills. Ecol Eng 51:8387. DOI: 10.1016/j.ecoleng.2012.12.004.

Yee TW, Mitchell ND.2002. Generalized additive models in plant ecology. J Veg Sci 157: 141-56. DOI: 10.2307/3236170.

Yi YJ, Cheng X, Yang ZF, Zhang SH. 2016. Maxent modeling for predicting the potential distribution of endangered medicinal plant $(H$. riparia Lour) in Yunnan. China Ecol Eng 92: 260-269. DOI: 10.1016/j.ecoleng.2016.04.010

Zhang X, Li G, Du S. 2018. Simulating the potential distribution of Elaeagnus angustifolia $\mathrm{L}$ based on climatic constraints in China. Ecol Eng 113: 27-34.

Zhu GP, Gariepy TD, Haye T, Bu WJ. 2017. Patterns of niche filling and expansion across the invaded ranges of Halyomorpha halys in North America and Europe. J Pest Sci 90: 1-13. DOI: 10.1007/s10340-0160786-z. 